\title{
Inge Jonsson
}

Göran Rossholm E Boel Westin

Professor emeritus Inge Jonsson, hedersmedlem i Svenska litteratursällskapet i Finland, har gått bort 9I år gammal. Inge Jonsson (1928-2020) växte upp i Stockholm. Han blev filosofie magister 1953 och disputerade 196r i litteraturhistoria med poetik vid Stockholms universitet på avhandlingen Swedenborgs skapelsedrama De cultu et amore Dei. En studie av motiv och intellektuell miljö (I96I). Han blev docent samma år. Inge Jonsson är den främsta svenska Swedenborgsforskaren, och han publicerade ett flertal skrifter i ämnet, bland dem Swedenborgs korrespondenslära (I969). Somliga har utgetts på engelska.

Inge Jonsson utnämndes till professor i litteraturvetenskap I973 vid Stockholms universitet och blev snabbt prefekt vid dåvarande Litteraturvetenskapliga institutionen. Han blev dekanus vid Humanistiska fakulteten I978, var prorektor I984-I988 och utnämndes till universitetets rektor 1988 , en post han innehade till sin pensionering 1994. Han hade mängder med uppdrag i stiftelser, samfund och fonder och var medlem i ett flertal akademier, bland andra Kungl. Vetenskapsakademien, Kung1. Vitterhetsakademien och Kung1. Krigsvetenskapsakademien. Han var Vitterhetsakademiens preses under många år, ordförande i Riksbankens Jubileumsfond och under trettio år ordförande i Samfundet De Nio. Han ledde flera nationella utvärderingar av ämnet litteraturvetenskap och anlitades flitigt även av utländska universitet. Tidigt engagerade han sig i gymnasieutbildningen i litteratur och svenska och utgav tillsammans med andra en serie litteraturantologier för det nya svenska gymnasiet i slutet av I96o-talet. Han bidrog i högsta grad till tillkomsten och utformningen av Södertörns högskola.

Hans forskningsintressen var omfattande men rörde sig framför allt kring idéhistoriska perspektiv och olika typer av tolkningsfrågor. Idéer och teorier om ordens konst. Frän Platon till strukturalismen (I97I) är en klassiker. Vi är många som böjt våra huvuden över denna täta 
framställning, där man kan stryka för praktiskt taget varje mening. Numera finns boken också i digital form. Byråkrater och politiker i samtida litteratur var ett annat ämne som intresserade Inge Jonsson, ett ämne som utvecklas i Maktens verktyg (I978). Den litterära begreppshistorien utforskas i det idéhistoriska verket I symbolens hus (1986). Under senare år skrev han bland annat historiker över Vitterhetsakademien (2003) och Samfundet De Nio (2013) samt en biografi över Jacob Letterstedt (2015).

Som professor var Inge Jonsson sällsynt frisinnad och öppen för nya intryck och idéer, lika vänlig som lyhörd, men med kritisk blick när så krävdes. Vi lärde känna Inge som handledare, seminarieledare och administratör på Litteraturvetenskapliga institutionen på 1970- och 8o-talen. I den förstnämnda rollen var han alltid lyssnande, förtroendefull och vidsynt. Han intresserade sig för ämnen som låg långt ifrån hans egen forskning, bland annat genom att viga en hel termins seminarieserie åt den originelle danske strukturalisten Peter Brask. Han satt ofta i den gamla forskarsalen på Kungliga Biblioteket under I980-talet, och som doktorand var det lätt att komma till tals med honom. En rökpaus på trappan kunde utvecklas till samtal om allt inom liv och litteratur. Den som tenterade för Inge kunde räkna med att bli grillad, men samtidigt fanns utrymme för fria tolkningar och en uppsluppenhet inför litteraturens oändliga möjligheter.

Prefektens arbete skötte Inge Jonsson på det mest föredömliga sätt. Hans dörr var alltid öppen, och hur överhopat skrivbordet än var hade han tid för frågor och synpunkter. Hans inställning till reformförslag var genomgående positiv, och han intog en effektiv och konstruktiv attityd i administrativa frågor. Hans signum var snabba och väl underbyggda beslut med kortast möjliga väg till verkställighet. Ett bestående resultat av Inge Jonssons initiativkraft var hans del i inrättandet av ämnet idéhistoria vid Litteraturvetenskapliga institutionen. Trots allt högre chefspositioner på universitetet förblev han lika tillgänglig för oss - en kort promenad eller ett telefonsamtal bort. När vi på institutionen enades om ett förslag om korta årliga arbetsresor till universitet i utlandet för samtliga anställda, sökte vi rektor Jonssons välsignelse. Han gav omedelbart prov på sin administrativa kreativitet genom att understödja propån med hänvisning till betydelsen av arbetsmiljömässiga förbättringar. Samma år han 
pensionerades deltog han i institutionens resa till Trinity College i Dublin.

Inge Jonssons öppenhjärtighet och humor förblev alltid lika intagande, endast hans klädstil förändrades. Den jeanskostym han i bästa 70-talsstil bar under sin tid vid institutionen byttes sedermera ut mot mer konventionell klädsel. Han förenade på ett sällsynt vis auktoritet med ödmjukhet.

Vi minns Inge Jonsson med saknad och tacksamhet som en stor humanist. Han var inte endast en lärd och kritisk vetenskapsman utan även en djupt engagerad företrädare för alla de områden där humanister kan verka och göra nytta. 